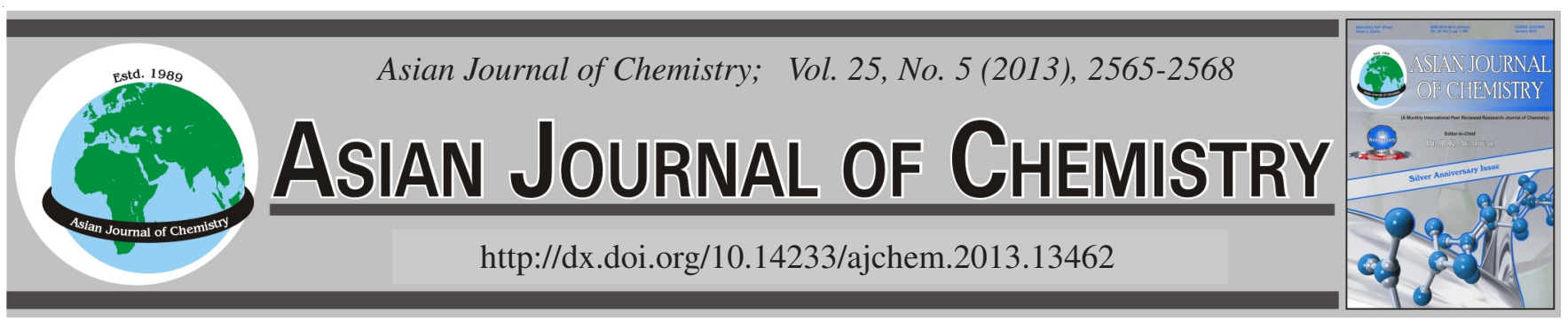

\title{
Removal of Orthophosphate from Municipal Wastewater Using Chemical Precipitation Process in Ahvaz Wastewater Treatment Plant, Iran
}

\author{
Mina Hormozi Nejad ${ }^{1}$, Afshin Takdastan ${ }^{2, *}$, Nematollah JaAfarzadeh ${ }^{3}$, \\ Mehdi Ahmadi Mogadam ${ }^{3}$ and NeZamaddin Mengelizadeh ${ }^{1}$
}

\begin{abstract}
${ }^{1}$ Department of Environmental Health Engineering, Ahvaz Jondi Shapour University of Medical Science, Ahvaz, Iran
${ }^{2}$ Department of Environmental Health and Environmental Technology Research Center, Ahvaz Jundi Shapur University of Medical Sciences, Ahvaz, Iran

${ }^{3}$ Department of Environmental Health Engineering and Environmental Technology Research Center, Ahvaz JundiShapur University of Medical Sciences, Ahvaz, Iran
\end{abstract}

*Corresponding author: E-mail: afshin_ir@yahoo.com

(Received: 18 January 2012;

\begin{abstract}
Phosphate removal such as orthophosphate, from municipal wastewater has become an environmental necessity, since the excessive phosphate ion content in municipal wastewater causes water eutrophication. According to environmental protection organization of Iran, maximum permissible concentration of residual phosphorus in treated municipal wastewater is $1 \mathrm{mg} / \mathrm{L} \mathrm{P}$. Almost all the phosphorus in natural water and wastewater is available in the form of phosphate. Phosphorus compounds in wastewater, after hydrolysis and biodegradation, change to solution orthophosphates. In this research, poly aluminium chloride and bentonite clay as nature coagulant were added and with low chemical cost, bentonite effect in improving poly aluminium chloride in municipal wastewater treatment, has been investigated. The research is a bench scale experimental type. Samples were collected from influent wastewater to primary and effluent of secondary clarifier and then effect of $\mathrm{pH}$ and dose of coagulant investigated on orthophosphate removal efficiency. The result show optimal conditions of compound of polyaluminium chloride and bentonite for removal of orthophosphate, COD, BOD and TSS in pH = 7 and optimal dose $15.55 \mathrm{mg} / \mathrm{L}$ polyaluminium chloride and $5.55 \mathrm{mg} / \mathrm{L}$ bentonite in influent wastewater to primary clarifier has been obtained 71.83, 46.1, 48.9 and $63.5 \%$, respectively. Under optimal condition, orthophosphate concentration was reached to $1 \mathrm{mg} / \mathrm{L}$. So this compound coagulant, in lowest dose and consequently chemical cost decrease, was selected as suitable coagulant in removal of orthophosphate of effluent of treatment plant.
\end{abstract}

Key Words: Eutrophication, Orthophosphate removal, Wastewater advanced treatment.

\section{INTRODUCTION}

According to environmental protection organization of iran, maximum permissible concentration of residual phosphorus in treated municipal wastewater for discharge is announced to be $1 \mathrm{mg} / \mathrm{L}$ phosphorus ${ }^{1}$. The adverse effects of eutrophication due to the presence of phosphate ions in water have been well documented. Phosphate ions discharged into water streams act as a major nutrient for aquatic life, which can lead to overgrowth of algae in lakes. This lowers the water quality by consumption of dissolved oxygen, resulting in the destruction of aquatic life ${ }^{2}$. The average concentration of total phosphorus in raw municipal wastewater is $8 \mathrm{mg} / \mathrm{L}$, about $10 \%$ of it, is removed in primary sedimentation and the other $10-20 \%$ in biological treatment, so the remainder $70 \%$ is often discharged by secondary effluent ${ }^{3}$. Common forms of phosphorus in wastewater are orthophosphate, polyphosphates and phosphates bonded to organic compounds. The last compounds release orthophosphate in aqueous solution too ${ }^{4}$. Nearly all the P-content of wastewater and natural waters may appear as phosphate ${ }^{5}$. It is obvious that advanced wastewater treatment facilities have to be employed to meet the discharge standard of phosphorus ${ }^{6-8}$.

Phosphorus removal can be accomplished either biologically or chemically'. Chemically,phosphate is most commonly removed by precipitation. Precipitation processes are capable of at least 90-95\% phosphorus removal at a reasonable $\operatorname{cost}^{10}$. Numerous substances have been used as coagulants, including aluminium and iron salts. In recent year, extensive researches have been conducted on coagulation process and various coagulants among polyaluminium chloride in literature. Polyaluminium chloride is a pre-polymerized coagulant is one of the most common coagulants in different water 
and wastewater treatment plants in countries such as USA, Canada, China, Italy, France and Britian ${ }^{11}$. This compound forms multi-core complex in wet environment and this unique characteristic helps polyaluminium chloride work efficiency during coagulation process ${ }^{12}$. In a polyaluminium chloride molecule, a large portion of aluminium appears in form of large oligomer polymers of aluminium ${ }^{13}$ cations with +7 ions a $\left[\mathrm{Al}_{13}(\mathrm{OH})_{24} \mathrm{O}_{4}\left(\mathrm{H}_{2} \mathrm{O}\right)\right]^{17}$. So polyaluminium chloride, to reason the most production of positive charge in proportion to non-polymer coagulants in organic matter and colloid particles negative charge neutralization in wastewater have be the most effective $^{13}$. Studies have been conducted to evaluate the potential of clay minerals like bentonite in the removal of phosphorus. The abundance of bentonite and it is low cost are likely to make it a strong candidate as an adsorbent for the removal of phosphorus from wastewater ${ }^{14,15}$.

Zouboulis and Tzoupanos ${ }^{16}$ reported that the phosphorus removal efficiency in wastewater, in dose $30-60 \mathrm{mg} / \mathrm{L}$ polyaluminium chloride has been obtained 75-98 \%. Wolf and Lind ${ }^{17}$, using bentonite clay, in dose $200 \mathrm{mg} / \mathrm{L}, 75 \%$ solution phosphorus after $1 \mathrm{~h}$ of settling time, removed of phosphorus.

In general, the degree of phosphorus removal by chemical precipitation is affected by many factors, such as $\mathrm{pH}$, alkalinity, coagulant dose and type, pollutants concentration in wastewater, speed of flash mixing and other interfering substances ${ }^{18}$. So in this study, investigated removal of orthophosphate from municipal wastewater in Ahvaz west wastewater treatment plant using chemical precipitation process by compound of polyaluminium chloride and bentonite clay.

\section{EXPERIMENTAL}

This research is a bench scale experimental type study. Influent wastewater to primary and effluent of secondary clarifier was collected from municipal wastewater treatment plant in Ahvaz city, Iran. The characteristics of wastewater are given in Table-1.

\begin{tabular}{lcc}
\multicolumn{3}{c}{ TABLE-1 } \\
\multicolumn{3}{c}{$\begin{array}{c}\text { PHYSICO-CHEMICAL CHARACTERTISTIC } \\
\text { OF MUNICIPAL WASTEWATER }\end{array}$} \\
\hline Parameters & $\begin{array}{c}\text { Influent wastewater } \\
\text { to primary clarifier }\end{array}$ & $\begin{array}{c}\text { Effluent of } \\
\text { secondary clarifier }\end{array}$ \\
\hline $\mathrm{pH}$ & 7 & 7 \\
$\mathrm{TP}(\mathrm{mg} / \mathrm{L})$ & 5 & 3 \\
Orthophosphate $(\mathrm{mg} / \mathrm{L})$ & $2.9-3.1$ & $2.7-2.85$ \\
COD $(\mathrm{mg} / \mathrm{L})$ & 279.68 & 71.33 \\
BOD $(\mathrm{mg} / \mathrm{L})$ & 142.67 & 35.65 \\
TSS $(\mathrm{mg} / \mathrm{L})$ & 320 & 46 \\
\hline
\end{tabular}

The coagulation experiments were carried out at the laboratory temperature $\left(25^{\circ} \mathrm{C}\right)$ using a jar test (model JLT6) with a 6 paddle stirrer. In each of the tests, $1000 \mathrm{~mL}$ of sample was taken in the jar. The $\mathrm{pH}$ was adjusted to desirable level with the addition of alkali $(1 \mathrm{~N} \mathrm{NaOH})$ or acid $(0.1 \mathrm{~N} \mathrm{HCL})$. The coagulant was added under stirring. Rapid mix took place for $2 \mathrm{~min}$, at a speed of $120 \mathrm{rpm}$, followed by slow mix for 10 $\mathrm{min}$, at $40 \mathrm{rpm}$. The settling period lasted for $1 \mathrm{~h}$. After the settling period, samples were taken and analyzed immediately for orthophosphate and sludge volume index (SVI) in all of the sample and COD, BOD and TSS in optimal condition of coagulant. At the end of each stage, the effect of each parameter on orthophosphate removal was determined using covariance analyzes and related graphs were depicted in an MS Excel sheet and $(\mathrm{p}<0.05)$ was significant.

In this study, the cyberscan $\mathrm{pH} 310$ digital $\mathrm{pH}$ meter (EUTECH company) was used and digital balance with Sartorius model with accuracy $0.0001 \mathrm{~g}$ for weight of the coagulant. Orthophosphate by ascorbic acid method to number $4500 \mathrm{PE}$ and COD by titration method to number $5220 \mathrm{C}$ using of DR/ 5000 spectrophotometer, SVI to $2710 \mathrm{D}$ method, BOD to BOD5 method to number $5210 \mathrm{~B}$ and TSS to weight method in standard methods for the examination of water and wastewater book (2005) was determined ${ }^{19}$.

\section{RESULTS AND DISCUSSION}

In this study, removal efficiency of orthophosphate by compound of polyaluminium chloride and bentonite clay was studied under various $\mathrm{pH}$ conditions. Figs. 1 and 2 shows the effect of $\mathrm{pH}$ on orthophosphate removal from influent wastewater to primary and effluent of secondary clarifier sing compound of polyaluminium chloride and bentonite clay.

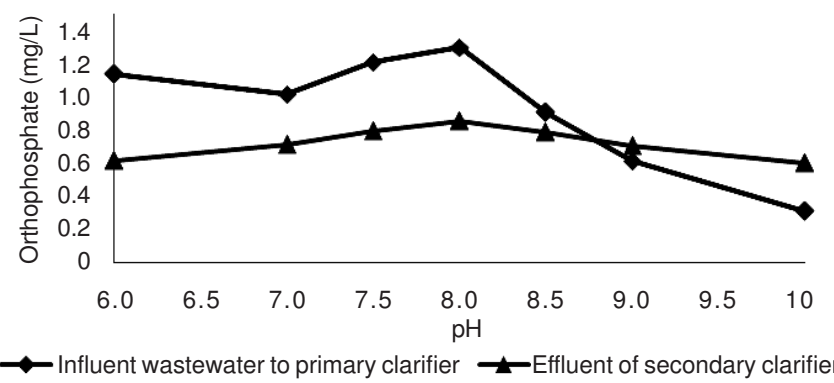

Fig. 1. Effect of $\mathrm{pH}$ on removal of orthophosphate concentration by addition of polyaluminium chloride and bentonite in every one of sampling points

Fig. 2 indicates that with increase of $\mathrm{pH}$, orthophosphate removal efficiency increases. The most efficiency of orthophosphate removal in $\mathrm{pH}=10$ in influent wastewater to primary and effluent to secondary clarifier respectively equal 89.67 and $78.45 \%$ was obtained. But due to the main aim in this test, orthophosphate concentration decrease to $1 \mathrm{mg} / \mathrm{L}$ (standard phosphorus in treatment plant effluent), so $\mathrm{pH}=7$ with orthophosphate concentration low of $1 \mathrm{mg} / \mathrm{L}$ in different points of sampling was selected as optimal $\mathrm{pH}$ that non-requirment to $\mathrm{pH}$ adjustment and change in wastewater natural conditions.

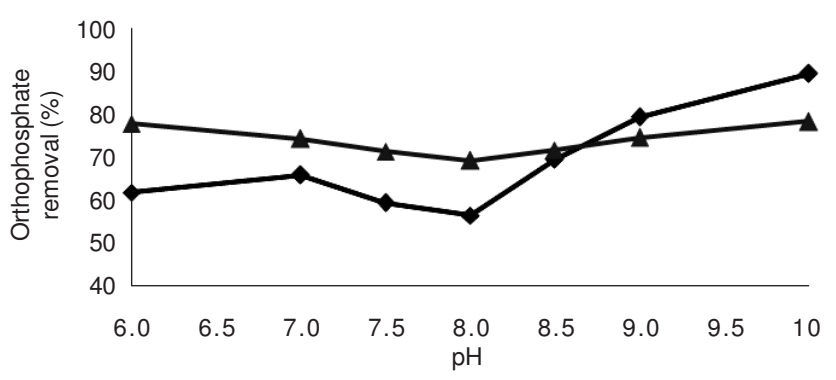

$\multimap$ Influent wastewater to primary clarifier —Effluent of secondary clarifier

Fig. 2. Effect of pH on removal (\%) of orthophosphate by addition of polyaluminium chloride and bentonite in every one of sampling points 


\begin{tabular}{|c|c|c|c|c|c|}
\hline \multicolumn{6}{|c|}{$\begin{array}{l}\text { TABLE-2 } \\
\text { RESULT OF THE DETERMINATION OF OPTIMUM DOSE OF COMPOUND COAGULANT IN INFLUENT } \\
\text { WASTEWATER TO PRIMARY CLARIFIER IN ORTHOPHOSPHATE REMOVAL }\end{array}$} \\
\hline $\begin{array}{l}\text { Coagulants } \\
\text { ratio }\end{array}$ & $\begin{array}{c}\text { Coagulant dose } \\
\text { PAC: Bentonite }(\mathrm{mg} / \mathrm{L})\end{array}$ & $\begin{array}{c}\text { Average of influent } \\
\text { orthophosphate (mg/L) }\end{array}$ & $\begin{array}{c}\text { Average of effluent } \\
\text { orthophosphate }(\mathrm{mg} / \mathrm{L})\end{array}$ & $\begin{array}{c}\text { Orthophosphate removal } \\
\text { efficiency }(\%)\end{array}$ & $\begin{array}{c}\text { SVI } \\
(\mathrm{mL} / \mathrm{g})\end{array}$ \\
\hline $1: 1$ & $10: 12.5$ & 3 & 1.365 & 54.50 & 36.0 \\
\hline $1: 2$ & $13.33: 8.3$ & 3 & 1.19 & 60.33 & 40.0 \\
\hline $1: 3$ & $15: 6.25$ & 3 & 1.02 & 66.00 & 45.0 \\
\hline $1: 3.5$ & $15.55: 5.55$ & 3 & 0.845 & 71.83 & 50.0 \\
\hline $1: 4$ & $16: 5$ & 3 & 0.731 & 75.61 & 51.7 \\
\hline $1: 4.5$ & $16.36: 4.54$ & 3 & 0.716 & 76.116 & 53.0 \\
\hline $1: 5$ & $16.66: 4.16$ & 3 & 0.702 & 76.60 & 54.0 \\
\hline $1: 6$ & $17.14: 3.57$ & 3 & 0.656 & 78.133 & 56.0 \\
\hline $7: 1$ & $17.5: 3.125$ & 3 & 0.596 & 80.133 & 59.0 \\
\hline
\end{tabular}

\begin{tabular}{|c|c|c|c|c|c|}
\hline \multicolumn{6}{|c|}{$\begin{array}{l}\text { TABLE-3 } \\
\text { RESULT OF THE DETERMINATION OF OPTIMUM DOSE OF COMPOUND COAGULANT IN } \\
\text { EFFLUENT OF SECONDARY CLARIFIER IN ORTHOPHOSPHATE REMOVAL }\end{array}$} \\
\hline $\begin{array}{l}\text { Coagulants } \\
\text { ratio }\end{array}$ & $\begin{array}{l}\text { Coagulant dose PAC: } \\
\text { Bentonite }(\mathrm{mg} / \mathrm{L})\end{array}$ & $\begin{array}{c}\text { Average of influent } \\
\text { orthophosphate }(\mathrm{mg} / \mathrm{L})\end{array}$ & $\begin{array}{c}\text { Average of effluent } \\
\text { orthophosphate }(\mathrm{mg} / \mathrm{L})\end{array}$ & $\begin{array}{c}\text { Orthophosphate removal } \\
\text { efficiency }(\%)\end{array}$ & $\mathrm{SVI}(\mathrm{mL} / \mathrm{g})$ \\
\hline $1: 1$ & $15: 12.5$ & 2.8 & 1.14 & 59.30 & 41.0 \\
\hline $1: 1.5$ & $18: 10$ & 2.8 & 1.10 & 60.714 & 43.0 \\
\hline $1: 2$ & $20: 8.33$ & 2.8 & 0.936 & 66.553 & 49.2 \\
\hline $1: 2.5$ & 21.43:7.143 & 2.8 & 0.83 & 70.36 & 56.0 \\
\hline $1: 3$ & $22.5: 6.25$ & 2.8 & 0.75 & 73.214 & 57.0 \\
\hline $1: 4$ & $24: 50$ & 2.8 & 0.60 & 78.571 & 59.0 \\
\hline $1: 5$ & $25: 4.166$ & 2.8 & 0.522 & 81.34 & 61.0 \\
\hline $1: 6$ & $25.71: 3.57$ & 2.8 & 0.445 & 84.107 & 63.0 \\
\hline $7: 1$ & $26.25: 3.125$ & 2.8 & 0.35 & 87.50 & 65.0 \\
\hline
\end{tabular}

Optimum $\mathrm{pH}$ of polyaluminium chloride in work of Zouboulis and Tzoupanos ${ }^{20}$ was range of 6.5-8.5 in phosphorus removal in municipal wastewater in dose of 40 and $50 \mathrm{mg} / \mathrm{L}$ polyaluminium chloride, phosphorus concentration decrease to $0.1 \mathrm{and} 0 \mathrm{mg} / \mathrm{L}$ respectively. Cucurella and Renman ${ }^{21}$, after using of ratio of bentonite clay to solution equal $1 / 20$ and in $\mathrm{pH}=4-12$, phosphorus absorption capacity in $\mathrm{pH}$ equal 7.5, 8.5 and 9 obtains respectively $3.5,4.3$ and $9.5 \mathrm{gp} / \mathrm{kgclay}$ as the most absorption capacity ${ }^{21}$, then the coagulants in certain $\mathrm{pH}$ in wastewater have be the most solubility and hydrolysis of them in wastewater rapidly and form hydrolysis productions that are metal ion with positive charge or metal hydroxids (hydrolysis productions depends to coagulant optimum $\mathrm{pH}$ ). So phosphate ion in wastewater was absorbed to metal ions with positive charge or metal hydroxides and after of the phosphate metal hydroxide formation, is settle and precipitation happen.

The influence of compound of polyaluminium chloride and bentonite dosage on orthophosphate removal during the coagulation in influent wastewater to primary and effluent of secondary clarifier was shown in Tables 2 and 3. From the experimental data it is observed that the residual concentration of orthophosphate ions decrease with the increases in quantity of compound coagulant. The most efficiency of orthophosphate removal with confidence of $95 \%$ obtain in dose $17.5 \mathrm{mg} / \mathrm{L}$ polyaluminium chloride and $3.12 \mathrm{mg} / \mathrm{L}$ bentonite in influent wastewater to primary clarifier and dose $26.35 \mathrm{mg} / \mathrm{L}$ polyaluminium chloride and $3.12 \mathrm{mg} / \mathrm{L}$ bentonite in effluent of secondary clarifier respectively reach to 80.13 and $87.5 \%$. Regarding the results of covariance test $(p<0.05)$ a significant difference can be found between coagulants dose and orthophosphate removal percent. Due to main aim in this tests, orthophosphate concentration decrease to $1 \mathrm{mg} / \mathrm{L}$, dose 15.55 $\mathrm{mg} / \mathrm{L}$ polyaluminium chloride and $5.55 \mathrm{mg} / \mathrm{L}$ bentonite in influent wastewater to primary clarifier and $20 \mathrm{mg} / \mathrm{L}$ polyaluminium chloride and $8.33 \mathrm{mg} / \mathrm{L}$ bentonite in effluent of secondary clarifier with final orthophosphate concentration and orthophosphate removal efficiency respectively in every one of the sampling points equal $(0.845$ and $71.83 \%)$ and $(0.94$ and $66.55 \%)$, as optimum dose in this test was selected. Optimum dose of polyaluminium chloride in findings of Zouboulis and Tzoupanos ${ }^{16}$, was range of 50-60 $\mathrm{mg} / \mathrm{L}$ that in this dose, phosphate concentration of $23 \mathrm{mg} / \mathrm{L}$, decrease to low of $1 \mathrm{mg} / \mathrm{L}$. According to Wolf and Lind $^{17}$, phosphorus removal per cent in dose $200 \mathrm{mg} / \mathrm{L}$ bentonite and after of 1 and $2 \mathrm{~h}$ of settling time respectively equal 75 and 84 $\%$ were obtained. Then determination of optimum conditions of coagulants in wastewater, depended to quality and quantity characterize of wastewater and chemical property that due to this factors, coagulants in certain range of dose, show the most removal of phosphorus.

The produced sludge in wastewater physical-chemical treatment is due to reaction between organic material, suspended solids and another contaminats in wastewater with productions of coagulant hydrolysis in wastewater. Tables 2 and 3 showed that with increase of coagulants dose, sludge volume index increase. In other words, it is noted that with increase of coagulants dose, form the coarse flocs, with the most solidity and high settling rate that to cause increase of produced sludge volume and consequently increase of sludge volume index. 
COD, BOD and TSS removal efficiency in every one of sampling points in optimum conditions of compound coagulant respectively equal (46.1, 48.9 and $63.5 \%)$ and (48.3, 55.5 and $65.1 \%$ ) obtain. Since coagulants performance in wastewater depened to different factors such as $\mathrm{pH}$ of wastewater, phosphorus concentration, organic matter, suspended solids and another contaminant in wastewater, so with increase of contaminants in wastewater, removal efficiency by coagulants decreases. In this test, observes in influent wastewater to primary clarifier, to reason of high concentration of TSS, COD and BOD and in the low dose of coagulant, removal efficiency of contaminants in proportion to effluent of secondary clarifier is low. Amuda and $\mathrm{Amoo}^{22}$, with compound of $25 \mathrm{mg} / \mathrm{L}$ polyelectrolyte and $100 \mathrm{mg} / \mathrm{L}$ ferric chloride, observed TSS, COD and phosphorus removal respectively reach to 99,91 and $97 \%$ that reason to has been the highest dose of coagulants for this contaminant removal. Due to aim in this research, was the orthophosphate removal by compound coagulant, so in optimum conditions of coagulant, has been investigated the suspended solids and organic matter removal and obtain the lowest removal efficiency of COD, BOD and TSS.

\section{Conclusion}

The work confirms, the optimal conditions for the process of orthophosphate removal from municipal wastewater by treating it with compound of polyaluminium chloride and bentonite clay. The experimental data show that orthophosphate separation is a complex physicochemical process. Some authors believe that the chemical processes play a fundamental role and that elimination of phosphorus is the result of $\mathrm{AlPO}_{4}$ precipitation, which can be complicated by the simultaneous precipitation of $\mathrm{Al}(\mathrm{OH})_{3}$. These hydroxides perform a flocculant function, facilitating the separation of the precipitated orthophosphate. Other authors believe that the phenomena of flocculation and hydroxide formation are responsible for orthophosphate ion removal by absorption of the orthophosphate ions. Based on the studies conducted ${ }^{23}$, we believe that the two type of phenomena work simultaneously.

Orthophosphate removal efficiency using coagulants, depends to coagulation conditions, wastewater quality, treatment process and chemical property.

Influent point to primary clarifier, to reason the less dose of compound coagulants for orthophosphate removal and decrease of chemical cost in proportion to effluent point of secondary clarifier, was selected as the optimum sampling point. Also removal efficiency of COD, BOD and TSS by compound coagulant and in this sampling point respectively reach to $46.1,48.9$ and $63.5 \%$. Since influent wastewater to primary clarifier should not containing the low concentration of organic material such as COD and BOD for wastewater biological treatment in aeration chamber, so the highest removal efficiency of this contaminants, before of biological treatment, disorder in wastewater biological treatment process. Due to removal efficiency of organic matter in this tests, so chemical precipitation process can not be disorder in wastewater biological treatment process. In effluent point of secondary clarifier, to reason the highest dose of coagulant and increase of the chemical costs and non-settling chamber in Ahvaz west wastewater treatment plant, so establishment of mixing, flocculation and settling chamber, cause to increase of the costs in wastewater treatment process units, so selection of this point as the optimum sampling point, is not economical.

\section{ACKNOWLEDGEMENTS}

This Research was Supported by Techniques and Researches Centre of Environmental Ahvaz Jondi Shapour University of Medical Science and Health College Laboratory in this University for the promotion of science.

\section{REFERENCES}

1. Enviromental Protection Organization of Iran, Executive Bylaws for Paragraph $(\mathrm{C})$ of Article 104 and Article 134 of the Third-5 year plan of the Islamic Republic of Iran (2001).

2. D.J. Conley, H.W. Paerl, R.W. Howarth, D.F. Boesch, S.P. Seitzinger, K.E. Havens, C. Lancelot and G.E. Likens, Science, 323, 1014 (2009).

3. R.K. Linsley, J.B. Franzini, D.L. Freyberg and G. Tchobanoglous, Water Resources Engineering, McGraw-Hill, Singapore, edn 4, pp. 154-166 (1992).

4. O. Mahmut and S. Ayhan, Turk. J. Eng. Environ. Sci., 27, 227 (2003).

5. J.Q. Jiang and N.J. Graham, Water SA, 24, 237 (1998).

6. J-.S. Nam and C.Y. Kim, J. Non-Crystalline Solids, 354, 5009 (2008).

7. M. Koiv, M. Liira, U. Mander, R. Motleb, C. Vohla and K. Kirsimae, Water Res., 44, 5232 (2010).

8. L. Lupa, P. Negrea, A. Negrea, A. Iovi, L. Cocheci and G. Mosoarca, J. Chem. Eng., 25, 9 (2008).

9. D.D. Heas, M. Wentzel and Ekama, Water SA, 26, 439 (2000).

10. E. Paul, M.L. Laval and M. Sperandio, Environ. Tech., 22, 1363 (2001).

11. K. Howe, J.C. Crittenden, D.W. Hand, R.R. Trussell and G. Tchobanoglous, Water Treatment:Principles and Design, edn. 3, pp. 340-380 (2011).

12. S. Shanawaz, Y. Yoon, G. Amy and J. Yoon, Chmosphere, 57, 1115 (2004).

13. K. Mccurdy, K. Carlson and D. Gregory, Water Res., 38, 486 (2004).

14. H. Sool Lee, S. Park and T. Yoon, Proc. Biochem., 38, 81 (2002).

15. I. Bamidele, O. Owolabi and L. Emmanuel, J. Hazard. Mater, 184, 731 (2010).

16. A.I. Zouboulis and N.D. Tzoupanos, Desalination, 250, 339 (2010).

17. J.E. Wolfe and O.T. Lind, Hydrobiologia, 610, 211 (2008).

18. M. James, P.L. Ebeling Sibrell, S.R. Ogden and S.T. Steven, Aquacult. Eng., 29, 23 (2003).

19. AWWA, WEF, APHA, Standard Methods for the Examination of Water and WasteWater, Washington D.C, USA, edn. 21 (2005).

20. A.I. Zouboulis and N.D. Tzoupanos, J. Hazard. Mater., 162, 1379 (2009).

21. V. Cucurella and G. Renman, J. Environ. Qual., 38, 381 (2009).

22. O.S. Amuda and I.A. Amoo, J. Hazard. Mater., 141, 778 (2007).

23. H. Roques, Fondements Theoretiques du Traitement chimique des eaux, Vol. II, Ed. Technique et documentation-lavoisier, II rue Lavoisier-F 75384 Paris, Cedex 08, 40 (1990). 